\title{
AS DEFINIÇÕES DE MUSEU E A RELAÇÃO COM A EDUCAÇÃO MUSEAL EM DISSERTAÇÕES E TESES BRASILEIRAS
}

\author{
Carla Krupczak? \\ Joanez Aparecida Aires² \\ Camila Silveira ${ }^{3}$
}

\begin{abstract}
RESUMO
Este artigo objetiva mapear e analisar as mudanças nas definições de museu no Brasil e como estas se relacionam com a educação museal a partir da análise da produção científica brasileira. Esta é uma pesquisa qualitativa bibliográfica. Os dados foram constituídos a partir do Catálogo de Teses e Dissertações da CAPES, no período de 1987 a 2017, em intervalos de dez anos, e explorados por meio da Análise de Conteúdo. Os resultados mostram que as definições de museu mudaram ao longo do tempo, passando a valorizar mais as práticas educativas. Entretanto, mais da metade das pesquisas não exibe uma definição direta de museu. A falta de clareza conceitual sobre educação museal pode contribuir para que tendências pedagógicas menos críticas aconteçam, comprometendo as potencialidades educativas destas instituições.
\end{abstract}

Palavras-chave: Educação em museus. Práticas museais. Ações educativas museais.

\section{MUSEUM DEFINITIONS AND THE RELATIONSHIP WITH MUSEUM EDUCATION IN BRAZILIAN DISSERTATIONS AND THESES}

\begin{abstract}
This article aims to map and analyze changes in museum definitions in Brazil and how they relate to museum education from the analysis of Brazilian scientific production. This is a qualitative bibliographic research. The data was constituted from the CAPES

1 Doutoranda do Programa de Pós-Graduação em Educação em Ciências e em Matemática da Universidade Federal do Paraná (UFPR), Curitiba, Paraná, Brasil. ORCID: http://orcid.org/0000-0003-0692-2789. E-mail: carlak.quim@gmail.com

2 Doutora em Educação Científica e Tecnológica pela Universidade Federal de Santa Catarina (UFSC). Professora do Departamento de Química e do Programa de PósGraduação em Educação em Ciências e em Matemática da Universidade Federal do Paraná (UFPR), Curitiba, Paraná, Brasil. ORCID: http://orcid.org/0000-0002-2925-0826. E-mail: joanez.ufpr@gmail.com

3 Doutora em Educação para a Ciência pela Universidade Estadual Paulista Júlio de Mesquita Filho (Unesp/Bauru). Professora do Departamento de Química e do Programa de Pós-Graduação em Educação em Ciências e em Matemática da Universidade Federal do Paraná (UFPR), Curitiba, Paraná, Brasil. ORCID: http://orcid.org/0000-0002-6261-1662. E-mail: camilasilveira@ufpr.br
\end{abstract}


Thesis and Dissertations Catalog from 1987 to 2017 in ten-year intervals and explored through Content Analysis. The results show that museum definitions have changed over time giving more value to educational practices. However, more than half of the studies do not show a direct definition of a museum. The lack of conceptual clarity about museum education can contribute to less critical pedagogical trends compromising the educational potential of these institutions.

Keywords: Museum education. Museum practices. Museum educational actions.

\section{DEFINICIONES DEL MUSEO Y LA RELACIÓN CON LA EDUCACIÓN MUSEAL EN LAS DISERTACIONES Y TESIS BRASILERAS}

\section{RESUMEN}

Este artículo tiene como objetivo mapear y analizar los cambios en las definiciones de museo en Brasil y cómo estas se relacionan con la educación museística a partir del análisis de la producción científica brasilera. Se trata de una investigación bibliográfica cualitativa. Los datos fueron relevados del Catálogo de Tesis y Disertaciones CAPES, de 1987 a 2017, en intervalos de diez años, y explorados a través del Análisis de Contenido. Los resultados muestran que las definiciones de museo han cambiado con el tiempo, dando más valor a las prácticas educativas. Sin embargo, más de la mitad de las investigaciones no muestran una definición directa de museo. La falta de claridad conceptual sobre la educación museística puede contribuir a tendencias pedagógicas menos críticas, comprometiendo el potencial educativo de estas instituciones.

Palabras clave: Educación en museos. Acciones educativas museales. Prácticas museales.

\section{INTRODUÇÃO}

A cultura é um importante elo de comunicação entre os diversos povos (FRANCO, 2019). Mas, cada ser humano seria fruto apenas da cultura local? "A ciência hoje coloca nossa história pessoal, familiar e coletiva num pequeno tubo de ensaio; os testes de DNA nos evidenciam que somos resultado de pontos híbridos, de múltiplas origens, muitas vezes distantes da fração do mundo em que habitamos" (FRANCO, 2019, p. 14).

Portanto, por vezes, o DNA pode mostrar que as pessoas fazem parte de culturas que negligenciam e até desprezam, e isso pode mudar a forma como elas se relacionam com o passado e com o sentimento de pertencimento. Nesse sentido, o museu tem a função de guardião da memória e da cultura (FRANCO, 2019). Mas, afinal, o que é um museu? 
A definição internacional atual desta instituição, de acordo com o International Concil of Museums (ICOM), aprovada na Assembleia Geral de Viena em 2007, é:

Um museu é uma instituição permanente, sem fins lucrativos, a serviço da sociedade e do seu desenvolvimento, aberta ao público, que adquire, conserva, pesquisa, comunica e exibe o patrimônio tangível e intangível da humanidade e do meio ambiente para fins educacionais, de estudo e entretenimento (ICOM, 2020, s.p., tradução nossa).

Já no contexto brasileiro, a Lei $n^{\circ} 11.904$, de 14 de janeiro de 2009, define, no Art. $1^{\circ}$, que:

Consideram-se museus, para os efeitos desta Lei, as instituições sem fins lucrativos que conservam, investigam, comunicam, interpretam e expõem, para fins de preservação, estudo, pesquisa, educação, contemplação e turismo, conjuntos e coleções de valor histórico, artístico, científico, técnico ou de qualquer outra natureza cultural, abertas ao público, a serviço da sociedade $e$ de seu desenvolvimento (BRASIL, 2009, s.p.).

Apesar das definições serem muito parecidas em determinados aspectos, existem algumas distinções. Por exemplo, uma diferença é que na versão brasileira nota-se a palavra 'interpretam', que não existe no conceito do ICOM. Este termo dá uma conotação de criação de sentidos próprios, o museu parece ter liberdade de expressão para interpretar as coleções de diferentes formas.

Portanto, pode-se perceber que as definições de museu podem variar de acordo com o contexto histórico e político de determinado grupo de pessoas. E, se o conceito desta instituição muda, então varia a forma como uma sociedade entende a função do museu e a educação que ocorre dentro dele. Isso se reflete nas pesquisas e no entendimento acadêmico sobre esses conceitos ao longo do tempo. Assim, esta pesquisa tem o objetivo de mapear e analisar as mudanças nas definições de museu no Brasil e como estas se relacionam com a educação museal a partir da análise da produção científica brasileira, em particular de teses e dissertações da área de Ensino e Educação. 


\section{OS MUSEUS E A EDUCAÇÃO MUSEAL}

Os museus têm sua origem no hábito do ser humano de colecionar objetos por motivos materiais, culturais, científicos, entre outros. Existem registros de espaços museais há milhares de anos, mas a instituição como é conhecida atualmente remonta-se ao século XVIII. No percurso histórico de desenvolvimento dessas instituições foram assumindo, cada vez mais, o papel de ambientes que promovem a cidadania, educação e cultura (IBRAM, 2018).

Para sobreviver na sociedade o museu deve evoluir, passar por mudanças, e sempre pensar nas seguintes perguntas: "A que vêm os museus? Que histórias estão eles a contar? A quem os museus se dirigem? Com quem dialogam? Museu, por quê? E para quem?" (FRANCO, 2019, p. 17).

O museu pode usar seus objetos para sensibilizar o público. Da mesma forma que um teste de DNA mostra a pluralidade de origens das pessoas, os objetos museais devem indicar uma variedade de culturas. Pois, apenas uma pequena parte da história está registrada na linguagem escrita, então os itens materiais são registros importantes da narrativa temporal humana. Além disso, um mesmo objeto pode ter significados variados na história e ser ressignificado em cada exposição (FRANCO, 2019). Como afirma Cury (2013, p. 14) "o acervo é ilimitado, plural, multifacetado; que pode ser fragmentado e reinterpretado; que no conjunto ou segmentado em coleções ou agrupamentos, o acervo é 'obra aberta' sustentada no conhecimento inerente à instituição". Por isso, os museus foram e são usados como forma de reforçar discursos políticos.

Nesse sentido, Franco argumenta que "O compromisso contemporâneo do museu é fazer com que a história da humanidade e de sua comunidade possa ser transmitida para o futuro, por meio dos objetos, sob a ótica do conhecimento humano" (FRANCO, 2019, p. 19). Logo, os museus são locais de reflexão e devem ser variados, transdisciplinares e se relacionar com diversos públicos, de forma a se adaptar à evolução da sociedade. O museu não é neutro, mas espaço de discussão, resistência, 
ruptura de preconceitos, reconhecimento de mudanças sociais e respeito às diferenças (FRANCO, 2019). Percebe-se então, que o museu tem função educacional.

A implementação de ações educativas nos museus brasileiros começou em 1927, com a criação do Serviço de Assistência ao Ensino do Museu Nacional. Destaca-se o empréstimo de peças às escolas, de forma a divulgar o que era estudado no museu (CAZELLI; VALENTE, 2019). Em 1956 aconteceu, em Ouro Preto, Minas Gerais, o I Congresso Nacional de Museus, no qual foi discutido o que significava educação em museus. Em 1958 realizou-se, no Rio de Janeiro, o Seminário Regional Latino-Americano da Unesco sobre o papel Educativo dos Museus. Este evento é considerado um marco na área, pois definiu os rumos da educação museal da época e originou diversas publicações técnicas. Neste período, os museus concentraram-se em receber estudantes para visitas guiadas (este termo não é mais utilizado, pois pressupõe que o público é totalmente ignorante) (IBRAM, 2018).

Em 2003, com o lançamento da Política Nacional de Museus (PNM), formou-se a Rede de Educadores em Museus (REM), que passou a repensar a educação museal. Em 2009, foi criado o Instituto Brasileiro de Museus (Ibram), que no ano seguinte realizou o primeiro Encontro dos Educadores de Museus, do qual resultou a Carta de Petrópolis. Este documento forneceu as bases para a criação de uma Política Nacional de Educação Museal, a qual foi aprovada em 2017 no 70 Fórum Nacional de Museus (IBRAM, 2018). "A Política Nacional de Educação Museal (PNEM) tem, entre seus objetivos, direcionar a realização das práticas educacionais em instituições museológicas, subsidiando a atuação dos educadores" (IBRAM, 2018, p. 43). No entanto, mesmo antes da PNEM, o Estatuto dos Museus já colocava no Art. 29 que "os museus deverão promover ações educativas, fundamentadas no respeito à diversidade cultural e na participação comunitária, contribuindo para ampliar 0 acesso da sociedade às manifestações culturais e ao patrimônio material e imaterial da Nação" (BRASIL, 2009, s.p.). 
No entanto, Sardelich (2017) afirma que, por muito tempo, a educação museal foi entendida apenas como complementação pedagógica da escola, ocorrendo uma escolarização das práticas museais. Assim, "[...] a instrução formal obrigatória tinha como complemento 'natural' as visitas a museus. Era o ideal da 'lição das coisas', no qual o aluno visitava o museu para observar 'ao vivo' o que havia sido ensinado 'em teoria' nos bancos escolares" (MARANDINO, 2008, p. 9). Entretanto, Macmanus (2013) coloca que o museu, diferentemente da escola, é um espaço não formal de educação, marcado pela livre escolha. Isto quer dizer que o indivíduo vai lá porque quer e aprende sobre algo que Ihe interessa com base em seus conhecimentos anteriores.

Portanto, a educação no espaço do museu não pode ser do tipo que atua na simples transmissão de informação. Ela é "[...] ação revestida de criticidade. Dessa forma, o museu deve ser crítico, da mesma forma que o projeto educacional e o educador, para que a ação educacional seja eficaz, i.e., para que o usuário do museu participe do processo museal criticamente" (CURY, 2013, p. 14). Assim, a educação no museu deve ser baseada na comunicação e

\begin{abstract}
Comunicação é - diferentemente do que propõe o modelo hegemônico, mas falido - encontro, troca e negociação do significado da mensagem museológica. Essa concepção equilibra (sem a intenção de neutralizar) o poder dos polos emissor e receptor, pois os dois atuam como sujeitos do processo. Às vezes, os papéis se invertem: o emissor estrutura a mensagem a partir das características do público. Aqui ele é receptor antes de ser emissor. O receptor torna-se emissor ao apropriar-se da mensagem museológica, ressignificá-la e expressá-la no museu e em seu contexto cotidiano (CURY, 2013, p. 17).
\end{abstract}

Esta comunicação é complexa, pois envolve uma negociação dos significados da mensagem que um objeto ou exposição passam, sendo um jogo de poder. Assim, o público é ativo, participando da ressignificação das mensagens museológicas. A educação só acontece se a comunicação ocorrer e as pessoas incorporarem o comunicado do museu às suas vidas (CURY, 2013). 
A escola preocupa-se com a formação integral do estudante. De acordo com Cury, "no ambiente museal ensina-se e aprende-se a refletir sobre o patrimônio, a olhar para objetos e pensar sobre eles e, sobretudo, a indagar sobre os seus valores patrimoniais" (CURY, 2013, p. 23). Dessa forma, a escola precisa agir junto com o museu para atingir a formação integral. Marandino (2008) defende que estas instituições não podem ser vistas como categorias isoladas, mas devem ser entendidas como parte de um contínuo, de uma formação educacional completa. No mundo todo o público mais significativo nos museus é o escolar. No caso do Brasil, pesquisa de Cazelli (2005) aponta que, para pessoas das classes sociais mais baixas, a escola é a única forma de acesso às instituições culturais.

Portanto, é preciso construir uma proposta educacional que favoreça os estudantes, o que só é possível se os conflitos entre as duas instituições forem superados. O professor deve perceber que o museu não é uma sala de aula ou um laboratório que a escola não tem. Mas, que é um espaço cultural vasto, que pode abordar muito mais que um componente curricular (CURY, 2013). É importante que o docente conheça o museu antes de levar suas turmas, para saber o que existe lá, que tipo de informação os alunos vão encontrar. No entanto, sabe-se que os professores nem sempre tem tempo para fazer tal visita antecipada e, por esse motivo, os educadores de museus devem disponibilizar documentos para os docentes. Podem ser panfletos que indicam o que está sendo abordado em determinada exposição, mapas do museu e de como chegar ao local, informações sobre a acessibilidade do prédio, sobre espaço para as crianças comerem, entre outros (MACMANUS, 2013). Afinal, "a aprendizagem é um processo cumulativo no qual sempre se está adicionando algo, conquistando algo, que depende de motivação e de seu estado físico naquele momento. Caso você esteja cansado ou tenso no momento, fica mais difícil aprender" (MACMANUS, 2013, p. 35). Por isso, é importante que as crianças fiquem confortáveis, que saibam onde fica o banheiro, onde podem beber água ou comer. 
Sobre as tendências da educação museal, Sardelich (2017) argumenta que existem na literatura cinco grandes tendências: canônica, instrutora, por descoberta, construtivista e reconstrutora, apresentadas no Quadro 1.

QUADRO 1 - Tendências da educação museal, de acordo com Sardelich (2017)

\begin{tabular}{|c|c|c|c|}
\hline $\begin{array}{c}\text { Tendências da } \\
\text { educação } \\
\text { museal }\end{array}$ & Visão do museu & $\begin{array}{l}\text { Tipo de } \\
\text { exposição }\end{array}$ & $\begin{array}{c}\text { Visão de educação e } \\
\text { educador }\end{array}$ \\
\hline Canônica & $\begin{array}{l}\text { O museu é um } \\
\text { espaço de } \\
\text { conhecimento } \\
\text { sofisticado e } \\
\text { experiência } \\
\text { estética. }\end{array}$ & $\begin{array}{c}\text { Exposições com } \\
\text { estrutura linear } \\
\text { e cronológica. } \\
\text { Textos } \\
\text { elaborados e } \\
\text { complexos. }\end{array}$ & $\begin{array}{c}\text { Por vezes nem tem } \\
\text { educador. Espera que o } \\
\text { público seja passivo. } \\
\text { Relações hierárquicas entre } \\
\text { produtores (curador, } \\
\text { artista...) e receptores } \\
\text { (público). }\end{array}$ \\
\hline Instrutora & $\begin{array}{c}\text { O museu é o } \\
\text { espaço em que } \\
\text { o conhecimento } \\
\text { é transmitido de } \\
\text { forma } \\
\text { unidirecional, } \\
\text { sendo } \\
\text { instrumento para } \\
\text { a educação. }\end{array}$ & $\begin{array}{c}\text { Exposições } \\
\text { sequenciais, } \\
\text { cronológicas e } \\
\text { com } \\
\text { informações } \\
\text { ordenadas das } \\
\text { mais simples } \\
\text { para as mais } \\
\text { complexas. }\end{array}$ & $\begin{array}{l}\text { O educador é um guia ou } \\
\text { monitor que acompanha o } \\
\text { público em visitas guiadas, } \\
\text { reproduzindo o discurso do } \\
\text { especialista. Os visitantes } \\
\text { devem apenas ouvir. }\end{array}$ \\
\hline Por descoberta & $\begin{array}{l}\text { O museu é o } \\
\text { espaço da } \\
\text { descoberta, } \\
\text { diversão e } \\
\text { encontro, que } \\
\text { tem a } \\
\text { educação } \\
\text { como ponto } \\
\text { central. }\end{array}$ & $\begin{array}{l}\text { As exposições } \\
\text { são interativas, } \\
\text { com objetos } \\
\text { que podem ser } \\
\text { tocados. }\end{array}$ & $\begin{array}{c}\text { O visitante deve participar } \\
\text { do processo educacional } \\
\text { com suas experiências } \\
\text { anteriores. Apesar da } \\
\text { interatividade, existe } \\
\text { apenas uma verdade. O } \\
\text { educador é um facilitador } \\
\text { que deve levar o público a } \\
\text { elucidar a mensagem } \\
\text { predeterminada. }\end{array}$ \\
\hline Construtivista & $\begin{array}{c}\text { O museu é um } \\
\text { espaço que } \\
\text { promove } \\
\text { cidadania ativa } \\
\text { e } \\
\text { desenvolvimento } \\
\text { pessoal. }\end{array}$ & $\begin{array}{l}\text { As exposições } \\
\text { têm atividades } \\
\text { e recursos que } \\
\text { focam mais no } \\
\text { aprendiz do } \\
\text { que no } \\
\text { conteúdo. }\end{array}$ & $\begin{array}{c}\text { Preocupa-se em mostrar } \\
\text { diversas visões. Gera } \\
\text { oportunidades para diversos } \\
\text { tipos de aprendizagem. } \\
\text { educador deve harmonizar } \\
\text { o conhecimento do } \\
\text { visitante com o contexto do } \\
\text { museu. }\end{array}$ \\
\hline Reconstrutora & $\begin{array}{l}\text { O museu é o } \\
\text { local público de } \\
\text { construção de } \\
\text { conhecimento. }\end{array}$ & $\begin{array}{l}\text { As exposições } \\
\text { oferecem } \\
\text { dilemas e } \\
\text { deixam visíveis }\end{array}$ & $\begin{array}{c}\text { Baseia-se na pedagogia } \\
\text { crítica. O conhecimento é } \\
\text { entendido como } \\
\text { construção histórica e }\end{array}$ \\
\hline
\end{tabular}




\begin{tabular}{|c|c|c|c|}
\hline & Ele enfatiza as & relações de & social. O educador é uma \\
relações entre & poder e saber, & pessoa que discute com o \\
diferentes & questionam & público, aprendendo com \\
culturas e & quem fala, & ele. A educação é um ato \\
prioriza a & como fala e & de reflexão e criação de \\
democracia. & com que & novas narrativas. \\
& objetivo. & \\
\hline
\end{tabular}

FONTE: as autoras (2020).

Cada museu vai adotar uma tendência de educação, que vai servir de orientação para as atividades realizadas. Tal escolha ocorre de acordo com a forma como o museu se entende na sociedade e como vê sua função educacional (SARDELICH, 2017). Por exemplo,

\begin{abstract}
Avaliar as ações educativas, ou a exposição como um todo, vai depender de como o museu entende o termo aprendizagem. Se, para ele, aprendizagem é um processo, então se deve avaliar como o apoio a este processo está sendo oferecido. Se o museu acha que é um produto, então ele terá que avaliar sim o que a pessoa entende de algum conteúdo (MACMANUS, 2013, p. 51-52).
\end{abstract}

Em outros termos, a concepção de educação das instituições orienta as ações realizadas pelos museus e suas atividades seguem determinadas tendências educacionais. Destarte, se os profissionais da instituição têm clareza das concepções que embasam as suas práticas educativas, o trabalho torna-se mais relevante e de maior alcance (MARANDINO, 2008). Por isso, é preciso investir na formação dos educadores de museus, mas, conforme apontam Tran et al. (2019), muitas vezes, devido à escassez de recursos, os museus optam por investir na infraestrutura e nas coleções e deixam a formação dos profissionais museais de lado.

A dimensão educativa dos museus, para além das relações estabelecidas entre educadores e o público em geral, tem larga trajetória com professores e estudantes que visitam suas exposições. A parceria entre museu e escola é de muita reciprocidade e as análises sobre essa relação revelam também a necessidade da formação de professores e dos educadores museais no sentido de potenciar os processos educativos que envolvem esses sujeitos (CURY, 2013). Portanto, 
[...] é necessária a formação dos professores, oriundos das escolas, nas linguagens e práticas específicas do espaço museal, tanto quanto dos educadores de museus acerca dos objetivos e necessidades das escolas ao visitarem o espaço museal. Não se trata de subordinação de um ao outro, mas da possibilidade da interação pedagógica entre ambas instituições que respeite as missões e exigências particulares de cada uma (MARANDINO, 2008, p. 25).

Marandino (2008) afirma que a educação em museus envolve processos específicos, logo, as particularidades desse espaço fazem com que exista uma pedagogia museal. Esta pedagogia tem entre suas especificidades: (i) o tempo, que é curto, sem prazos, ordem sequencial ou urgência de aprendizado4; (ii) o espaço físico, que não conta com carteiras, por exemplo; (iii) os objetos, que são o centro do museu e (iv) a linguagem, que é uma adaptação de vários discursos e, em grande parte, visual. Em relação a este último aspecto:

O mediador deve, ao planejar suas ações e ao realizar a mediação com o público, considerar que este não deve ser exposto a longos períodos de exposição oral, não deve ser submetido à leitura de textos imensos, mas deve, sim, saber se localizar, se sentir à vontade para interagir, podendo dialogar com seus pares e com o mediador. Estes e outros elementos são decorrentes da especificidade que esses locais imprimem para ações educativas neles realizadas (MARANDINO, 2008, p. 20).

Além disso, é preciso que o educador de museus conheça o público. As especificidades dos visitantes definem como eles vão se relacionar e aprender no museu. Inclusive, diversas pesquisas buscam entender quais são os diversos públicos do museu (FALK, 2013; TRAINER et al., 2012; FALK, 2011), discutir como ocorre a aprendizagem no espaço museal e a avaliação desse processo (SOUZA; SILVA, 2016; OLIVEIRA et al., 2014; ALMEIDA; MARTÍNEZ, 2014; CHIN, 2004; FALK; DIERKING, 1995) e a formação dos profissionais dos museus (TRAN et al., 2019).

\footnotetext{
${ }_{4}$ Mesmo que o tempo das visitas aos museus seja curto, estas deixam memórias marcantes nas pessoas, como indica a pesquisa de Falk e Dierking (1995).
}

Revista Exitus, Santarém/PA, Vol. 11, p. 01 - 23, e020132, 2021. 


\section{METODOLOGIA}

Esta pesquisa é qualitativa bibliográfica, porque foram analisadas teses e dissertações, que são consideradas materiais de referência (GIL, 2002). Na pesquisa qualitativa os dados são majoritariamente descritivos e a análise prioriza os significados atribuídos aos objetos e situações.

A constituição dos dados ocorreu no Catálogo de Teses e Dissertações da Coordenação de Aperfeiçoamento do Pessoal de Nível Superior (CAPES). Este banco de dados existe desde 1987, então, foram analisados trabalhos publicados a partir de tal ano. O objetivo desta pesquisa é entender as mudanças nas definições de museu no Brasil ao longo do tempo e como estas se relacionam com a educação museal. Por isso, optou-se por constituir dados a cada dez anos, de modo a tentar identificar as diferenças dentro desses períodos de tempo. Para tanto, utilizamos as teses e dissertações defendidas nos anos de 1987, 1997, 2007 e 2017. Analisaram-se apenas as pesquisas produzidas em Programas de Pós-graduação das áreas de avaliação Educação ou Ensino. O termo de busca usado foi museu, o qual deveria estar no título, palavras-chave ou resumo dos trabalhos. As pesquisas foram codificadas de D1 a D49 (para as dissertações) e de T1 a T10 (para as teses). Esta codificação e as referências completas encontram-se no Material Complementar.

Os dados foram analisados via Análise de Conteúdo (BARDIN, 2004). Esta metodologia é composta de três momentos. No primeiro realiza-se a pré-análise, em que os textos, no caso desta pesquisa as teses e dissertações, são lidos e o corpus é definido. Na segunda etapa ocorre a codificação, que consiste em buscar unidades de contextos (partes dos textos) que possuam unidades de registro significativas (neste caso, frases que remetam à definição de museu e à educação museal). Então, as unidades de registro são agrupadas e reagrupadas em categorias temáticas. Neste artigo emergiram quatro categorias gerais: (1) ano e tipo; (2) região do país; (3) foco e (4) tipo de museu. E seis categorias específicas, voltadas para o objetivo geral desta pesquisa: (1) definição do ICOM, (2) definição da Lei 11.904; (3) museu como espaço educacional; (4) museu como espaço 
educacional e de memória, que preserva objetos significativos; (5) museu como espaço educacional, de lazer e deleite; e (6) museu como espaço educacional e divulgação da ciência, da história e de ideias. No último momento realiza-se a inferência, ou seja, a interpretação dos resultados e construção de conhecimento.

\section{RESULTADOS E DISCUSSÃO}

Foram encontradas 59 teses e dissertações, cuja distribuição por ano e tipo está na Tabela 1. A maioria dos trabalhos é de mestrado, apenas no ano de 2017 tem-se pesquisas de doutorado. Nota-se que de 2007 a 2017 houve um grande aumento da produção acerca da educação museal. Tal dado pode estar relacionado ao fato de que o número de Programas de PósGraduação quase dobrou nesse período (MCTIC, 2019). Além disso, o Brasil vivia um cenário de valorização dos museus, com Políticas Públicas no campo da Cultura, da Educação e da Popularização e Divulgação Científica. Assim, o aumento da pesquisa também pode ter relação com o aumento de políticas públicas para museus, como o Plano Nacional Setorial de Museus (IBRAM, 2010) e o Caderno da Política Nacional de Educação Museal (IBRAM, 2018), e com a criação do lbram, que ocorrev em 2009.

TABELA 1 - Distribuição das pesquisas por ano e tipo

\begin{tabular}{ccc}
\hline Ano & Dissertações & Teses \\
\hline 1987 & 2 & 0 \\
\hline 1997 & 1 & 0 \\
\hline 2007 & 11 & 0 \\
\hline 2017 & 35 & 10 \\
\hline
\end{tabular}

Fonte: as autoras, 2020.

A distribuição dos trabalhos por região do país está na Tabela 2. Percebe-se que a produção concentra-se no Sudeste. Este dado pode ser explicado pela aglomeração de cursos de Pós-Graduação e de investimento nessa região. Segundo Sidone et al. (2016), entre 2006 e 2009 mais de $50 \%$ da pesquisa científica brasileira acumulava-se no Sudeste. 
TABELA 2 - Distribuição das pesquisas por região do país

\begin{tabular}{ccc}
\hline Região & $\mathbf{N}^{\circ}$ de pesquisas & Porcentagem \\
\hline Sudeste & 34 & $57,6 \%$ \\
\hline Sul & 12 & $20,3 \%$ \\
\hline Nordeste & 9 & $15,2 \%$ \\
\hline Centro-Oeste & 2 & $3,4 \%$ \\
\hline Norte & 2 & $3,4 \%$ \\
\hline
\end{tabular}

Fonte: as autoras, 2020.

Em relação ao foco das pesquisas sobre museus, definiram-se nove tipos, os quais estão descritos na Tabela 3.

TABELA 3 - Foco das pesquisas sobre museus

\begin{tabular}{l|c|c}
\hline Foco das pesquisas & $\begin{array}{c}\mathbf{N}^{\circ} \text { de } \\
\text { pesquisas }\end{array}$ & Porcentagem \\
\hline $\begin{array}{l}\text { Analisa as atividades realizadas pelos } \\
\text { museus e a potencialidade educativa } \\
\text { destas e/ou como ocorre a aprendizagem } \\
\text { nestas atividades. }\end{array}$ & 18 & $30,5 \%$ \\
\hline $\begin{array}{l}\text { Analisa como o público (escolar ou não) } \\
\text { relaciona-se com o museu. }\end{array}$ & 9 & $15,2 \%$ \\
\hline $\begin{array}{l}\text { Analisa as concepções do museu sobre } \\
\text { divulgação científica e/ou sua função } \\
\text { educacional no seu discurso e/ou em suas } \\
\text { exposições. }\end{array}$ & 9 & $15,2 \%$ \\
\hline $\begin{array}{l}\text { Analisa como os professores entendem e } \\
\text { usam o museu no ensino. }\end{array}$ & 5 & $8,5 \%$ \\
\hline $\begin{array}{l}\text { Analisa o acervo e a estrutura do museu e } \\
\text { como isso influencia a visita. }\end{array}$ & 4 & $6,8 \%$ \\
\hline $\begin{array}{l}\text { Analisa como os educadores de museus } \\
\text { agem e como entendem a aprendizagem } \\
\text { no espaço museal. }\end{array}$ & 4 & $6,8 \%$ \\
\hline $\begin{array}{l}\text { Analisa como professores e alunos criam } \\
\text { museus. }\end{array}$ & 4 & $6,8 \%$ \\
\hline $\begin{array}{l}\text { Analisa como ocorre a formação de } \\
\text { professores no e sobre o museu. }\end{array}$ & 3 & $5,1 \%$ \\
\hline $\begin{array}{l}\text { Analisa as ações educativas que existem } \\
\text { no museu e propõe uma. }\end{array}$ & 3 & $5,1 \%$ \\
\hline
\end{tabular}

Fonte: as autoras, 2020. 
Da Tabela 3 depreende-se que a maior parte das teses e dissertações analisa as atividades realizadas pelos museus e a potencialidade educativa destas e/ou como ocorre a aprendizagem nestas atividades. É interessante notar que apenas 5,1\% das investigações discute a formação de professores no e sobre o museu. Este é um dado preocupante, visto que, a educação no espaço museal se potencializa na atuação em parceria com as instituições formais de ensino. É preciso vencer a dicotomia e os conflitos entre estas instituições, o que só pode ser alcançado por meio de um trabalho comprometido com a formação de professores e educadores de museus (MARANDINO, 2008).

Quanto ao tipo de museu abordado nas pesquisas, dividimos os mesmos em quatro tipos: científicos, históricos, artes e todos os tipos, como indica a Tabela 4. Este último refere-se às investigações que analisaram vários tipos de museus ou os estudaram de forma genérica. Percebe-se que a maior parte dos trabalhos envolve museus de ciências.

TABELA 4 - Tipos de museus abordados pelas pesquisas

\begin{tabular}{ccc}
\hline Tipo de museu & $\mathbf{N}^{\circ}$ de pesquisas & Porcentagem \\
\hline Científico & 26 & $44,1 \%$ \\
\hline Histórico & 18 & $30,5 \%$ \\
\hline Artes & 8 & $13,6 \%$ \\
\hline Todos os tipos & 7 & $11,9 \%$ \\
\hline
\end{tabular}

Fonte: as autoras, 2020.

No que se refere à educação nos espaços museais, apenas três pesquisas a categorizam como educação informal (uma de 1997, outra de 2007 e a terceira de 2017). Outros 42 trabalhos nomeiam as ações educativas que ocorrem nos museus como educação não formal. E 14 teses e dissertações não citam uma classificação específica para estas atividades.

Sobre as definições de museu apresentadas nas teses e dissertações analisadas, as indicamos na Tabela 5. Foram definidas seis categorias principais e são apresentadas as quantidades de pesquisas de cada uma delas. Na Tabela 6 indicamos a distribuição por ano das categorias principais. 
TABELA 5 - Definições de museu encontradas nas teses e dissertações

\begin{tabular}{|c|c|c|c|}
\hline \multicolumn{2}{|l|}{ Definição } & Quantia & Categoria \\
\hline \multicolumn{2}{|c|}{ Definição do ICOM. } & $26(44,1 \%)$ & 1 \\
\hline \multicolumn{2}{|c|}{ Definição da Lei 11.904.} & $2(3,4 \%)$ & 2 \\
\hline \multirow{4}{*}{$\begin{array}{l}\text { Sem definição } \\
\text { explícita, mas } \\
\text { destaque para } \\
\text { alguns aspectos } \\
\text { do museu: }\end{array}$} & $\begin{array}{l}\text { Museu como espaço } \\
\text { educacional. }\end{array}$ & $13(22,0 \%)$ & 3 \\
\hline & $\begin{array}{l}\text { Museu como espaço } \\
\text { educacional e de memória, } \\
\text { que preserva objetos } \\
\text { significativos. }\end{array}$ & $9(15,2 \%)$ & 4 \\
\hline & $\begin{array}{l}\text { Museu como espaço } \\
\text { educacional, de lazer e } \\
\text { deleite. }\end{array}$ & $5(8,5 \%)$ & 5 \\
\hline & $\begin{array}{l}\text { Museu como espaço } \\
\text { educacional e divulgação } \\
\text { da ciência, da história e de } \\
\text { ideias. }\end{array}$ & $4(6,8 \%)$ & 6 \\
\hline
\end{tabular}

Fonte: as autoras, 2020.

TABELA 6 - Distribuição temporal das categorias

Categoria Quantidades de trabalhos por ano

\begin{tabular}{ccccc}
\hline & 1987 & 1997 & 2007 & 2017 \\
\hline 1 & 1 & 0 & 5 & 20 \\
\hline 2 & 0 & 0 & 0 & 2 \\
\hline 3 & 0 & 0 & 5 & 8 \\
\hline 4 & 1 & 0 & 0 & 8 \\
\hline 5 & 0 & 0 & 1 & 4 \\
\hline 6 & 0 & 1 & 0 & 3 \\
\hline
\end{tabular}

Fonte: as autoras, 2020.

Nota-se, ao analisar a Tabela 6, que a porcentagem de pesquisas que usam o conceito oficial de museu do ICOM (categoria 1) manteve-se constante de 2007 a 2017. Pois, em 2007 das 11 teses e dissertações, 5 usaram a definição do ICOM, correspondendo a 45,5\%. Em 2017, de 45 pesquisas, 20 usam o conceito, sendo 44,4\%. Assim, nos últimos dez anos, manteve-se a proporção de quase metade das pesquisas fundamentarem-se no ICOM, cuja definição é:

Um museu é uma instituição permanente, sem fins lucrativos, a serviço da sociedade e do seu desenvolvimento, aberta ao público, que adquire, conserva, pesquisa, comunica e exibe o patrimônio tangível e intangível da humanidade e do meio ambiente para fins 
educacionais, de estudo e entretenimento (ICOM, 2020, s.p., tradução nossa).

No entanto, esta definição está presente apenas nas pesquisas de 2017 (foram encontradas apenas pequenas variações, em função das diferentes traduções do original em inglês), pois esta foi aprovada em 2007. As investigações de 2007 ainda usam a definição anterior (salvo pequenas variações), que é de 2001, e não difere muito da definição atual:

O museu é uma instituição permanente, aberta ao público, sem fins lucrativos, a serviço da sociedade e de seu desenvolvimento, que adquire, conserva, pesquisa, expõe e divulga as evidências materiais e os bens representativos do homem e da natureza, com a finalidade de promover o conhecimento, a educação e o lazer (D4, p. 49).

Já o trabalho de 1987 usa a seguinte definição do ICOM, de 1968:

[...] museu é um estabelecimento de caráter permanente, administrado para interesse geral, com a finalidade de conservar, estudar, valorizar de diversas maneiras, e principalmente expor para deleite e educação do público, um conjunto de elementos de valor cultural (D1, p. 3).

Percebe-se que esta definição, mais antiga, fala apenas de "elementos de valor cultural", dando a impressão de referir-se apenas a objetos físicos, diferentemente do conceito atual, que se refere a "patrimônio tangível e intangível". Outro ponto a ser notado é que o texto de 1968 fala em "principalmente expor" como a finalidade do museu, destacando tal função das outras, o que não é feito na definição atual. Portanto, avista-se que os conceitos de museus mais antigos não ressaltavam a educação museal.

Na categoria 2 encontramos dois trabalhos que usam o conceito de museu da lei 11.904, a qual destaca o papel educacional da instituição:

Consideram-se museus, para os efeitos desta Lei, as instituições sem fins lucrativos que conservam, investigam, comunicam, interpretam e expõem, para fins de preservação, estudo, pesquisa, educação, contemplação e turismo, conjuntos e coleções de valor histórico, 
artístico, científico, técnico ou de qualquer outra natureza cultural, abertas ao público, a serviço da sociedade $e$ de seu desenvolvimento (BRASIL, 2009, s.p.).

As outras 31 teses e dissertações não definem museu de forma explícita e direta. No entanto, da leitura dos trabalhos foi possível inferir, pela interpretação dos textos, o que os autores entendem por esta instituição. Um aspecto foi comum: todas as pesquisas entendem o museu como espaço educacional. Não poderia ser diferente, visto que são investigações feitas por profissionais da educação. Destas 31 teses e dissertações, 13 focaram apenas na função educacional, formando a categoria 3. As outras 26 pesquisas destacaram, além desta, outras características do museu.

É preocupante que a maioria das pesquisas não tenha tomado o cuidado de definir explicitamente o que entende por museu. Por outro lado, todos os trabalhos reforçaram a função educativa desta instituição. E, que ela pode ter outras finalidades como a de preservação, lazer e deleite, divulgação e espaço cultural. Sendo que estas atribuições estão englobadas nas definições do ICOM e da Lei 11.904.

Na categoria 4 estão os nove trabalhos que definem museu como espaço educacional e de memória, que preserva objetos significativos. Isso pode ser notado na seguinte frase retirada de D46: "Todas essas discussões reforçam um aspecto das funções sociais museais: os museus são considerados lugares de memórias e a dimensão pedagógica está associada ao uso social dessas memórias" (D46, p. 103, grifo nosso). E também no seguinte trecho de T1:

O museu fica entendido, dessa forma, como lugar, espaço de memória, onde se deve depositar algo que guarde significado no presente por seus usos ou desusos e que possa vir a ser relevante ao futuro, como basilar de ações já praticadas, mas plausíveis de serem reinterpretadas em um novo contexto, tornando-se referência ao apresentar narrativas diversas para um mesmo contexto passado e propiciar tantas outras nos contextos que estão por vir, baseados em seu acervo e nas diversas configurações que cada olhar possibilita às peças, aos fatos e aos registros ali depositados (T1, p. 22, grifo nosso). 
A categoria 5 contém cinco trabalhos que destacam a função de deleite e lazer do museu. Vê-se isso na frase "[...] possam despertar o interesse dos estudantes para a percepção do Museu como espaço de prazer, de descoberta e de possível articulação entre as experiências vivenciadas e o espaço escolar" (D26, p. 66, grifo nosso).

A categoria 6 é composta de quatro pesquisas que afirmam que 0 museu deve ser divulgador da ciência, da história e de ideias. Tal fato aparece evidenciado na frase: "Os museus de ciência são reconhecidamente um espaço de popularização da ciência para o grande público" (D33, p. 22, grifo nosso).

Assim, constata-se neste artigo que a maior parte das pesquisas está na região Sudeste. Tal fato pode estar relacionado com o maior número de museus que existem nesta região. Segundo a plataforma Museusbr (IBRAM, 2020), a qual faz parte do Cadastro Nacional de Museus do Ibram, a região sudeste tem 1520 instituições museais, enquanto as regiões norte, centrooeste, nordeste e sul têm 182, 287, 848 e 1054 museus, respectivamente.

Os dados também indicam que a maioria das pesquisas analisa as atividades realizadas pelos museus e a potencialidade educativa destas e/ou como ocorre a aprendizagem nestas atividades. Poucas pesquisas concentram-se na formação de professores no e sobre o museu, o que é preocupante. A maioria das pesquisas utilizou museus científicos para os estudos. E mais de $71 \%$ dos trabalhos considera o espaço museal como local de educação não formal.

Apenas $41,1 \%$ das teses e dissertações analisadas usa a definição oficial do ICOM para museu. Este dado é surpreendente, visto que, se existe um conceito estabelecido para a instituição, esperava-se que a maioria dos trabalhos usasse tal definição. Mais de metade das pesquisas não faz menção explícita ao que entende por museu. Isso é preocupante, pois são estudos que acontecem na instituição museal, então, seria importante definir o que é tal local.

Entretanto, dentre as pesquisas que usaram a definição do ICOM, os conceitos eram diferentes, visto que trabalhos mais antigos usaram noções 
anteriores de museu. Notam-se, então, algumas diferenças. Por exemplo, a descrição de 1968 prioriza, como função da instituição museal, a exposição de objetos, colocando a educação em segundo plano. Já a definição atual do ICOM realça o papel educacional do museu.

Relativamente aos trabalhos que não possuíam definição explícita de museu, foi possível, pela leitura dos textos, identificar algumas características, destacadas pelos autores, como essenciais do museu. Todas as pesquisas entendem essa instituição como um espaço educacional, o que é esperado, visto que são trabalhos de Programas de Pós-graduação de Educação ou Ensino. Outras investigações realçaram as funções do museu de preservação de objetos e memórias, sendo, neste caso, muitas das pesquisas que envolveram estabelecimentos históricos. Algumas teses e dissertações, frequentemente as que estudaram espaços museais científicos, salientaram a obrigação de divulgar a ciência, a história e as ideias. O restante dos trabalhos ressaltou que o museu é espaço de lazer e deleite.

\section{CONCLUSÃO}

O objetivo desta investigação foi mapear e analisar as mudanças nas definições de museu no Brasil e como estas se relacionam com a educação museal a partir da análise da produção científica brasileira, em particular de teses e dissertações da área de Ensino e Educação. Os dados indicaram que cerca de metade dos trabalhos não explicita o que entende por museu. Dentre as pesquisas que utilizam uma definição precisa, a maioria usa a recomendada pelo ICOM. Assim, historicamente, as variações encontradas seguem as que foram adotadas pelo ICOM. As definições mais atuais são mais abrangentes e enfatizam mais a educação museal. Portanto, apesar da função educacional do museu sempre ter existido, ela ganhou destaque apenas recentemente, principalmente a partir da definição de 2007 do ICOM e das políticas de Educação Museal, como o Caderno da Política Nacional de Educação Museal (IBRAM, 2018). Além disso, notamos que a Educação Museal é mais enfatizada na área de Educação em Ciências, 
visto que a tipologia da maior parte dos museus presentes nos estudos analisados nesta pesquisa é de Ciência e Tecnologia.

Consideramos que conhecer a definição de museu dos pesquisadores é relevante porque ela esclarece sobre a forma como a educação é entendida neste espaço, como apontado por Sardelich (2017). Sobre a tendência educacional dos museus, percebe-se que a maioria deles segue a canônica ou instrutora, quando se considera que o ideal seria uma educação reconstrutora. Isso talvez possa ocorrer porque, apesar da definição do ICOM destacar o papel educacional dos museus, ela não explicita qual tendência deve ser seguida neste processo. Ela aborda apenas os papeis da instituição: "que adquire, conserva, pesquisa, comunica e exibe" (ICOM, 2020, s.p., tradução nossa) e não menciona a função dos visitantes. Nesse sentido, perguntamos se estes devem apenas ouvir, se deleitar e se entreter ou participar do processo de construção do conhecimento? Esta pergunta é especialmente pertinente no momento atual, em que o ICOM repensa a definição de museu. Portanto, este é um bom período para refletir sobre que tipo de educação museal deve ser fomentada e acrescentá-la na definição.

Como afirmam Brown e Mairesse (2018, p. 536, tradução nossa) "mais do que nunca, sem dúvida, o museu aparece como um híbrido complexo, dividido entre suas coleções, seu público e seus pesquisadores ou, de maneira mais global, seus usuários". Os autores apresentam as discussões que estão sendo feitas no âmbito dos eventos do ICOM e seus representantes regionais e enfatizam que o debate precisa levar em conta $\circ$ público dos museus. E, como grande parte dos visitantes são estudantes e professores, envolve reflexões sobre que tipo de educação estas pessoas desejam. Afinal, se o museu quiser ser mais democrático, todos os envolvidos precisam ser escutados.

Além disso, Brown e Mairesse (2018) notaram que as discussões e prioridades variavam de país para país. Assim, visto todas as diferenças regionais, em termos de condições sociais e culturais mundiais, caberia uma definição universal de museu? É possível abranger todas as funções sociais e 
necessidades de todos os povos (especialmente em termos de educação museal) em uma única definição? Consideramos que estas são questões que devem estar presentes nas reflexões atuais sobre educação museal.

\section{REFERÊNCIAS}

ALMEIDA, P.; MARTíNEZ, A. M. As pesquisas sobre aprendizagem em museus: uma análise sob a ótica dos estudos da subjetividade na perspectiva histórico-cultural. Ciência \& Educação, Bauru, v. 20, n. 3, p. 721-737, 2014.

BARDIN, L. Análise de conteúdo. 3. ed. Lisboa: Edições 70, 2004.

BRASIL. Lei $n^{\circ} 11.904$ de janeiro de 2009. Institui o Estatuto de Museus e dá outras providências. Brasília, DF, 14 jan. 2009. Disponível em: http://www.planalto.gov.br/ccivil_03/_Ato2007-2010/2009/Lei/L1 1904.htm. Acesso em: 12 fev. 2020.

BROWN, K., MAIRESSE, F. The definition of the museum through its social role. Curator: The Museum Journal, v. 61, n. 4, p. 525-539, 2018.

CAZELLI, S. Ciência, Cultura, Museus, Jovens e Escolas: quais as relações? 2005. 260 f. Tese (Doutorado em Educação) - Faculdade de Educação, Pontifícia Universidade Católica do Rio de Janeiro, Rio de Janeiro, 2005. Disponível em: http://www.fiocruz.br/brasiliana/media/tese_sibelecazelli.pdf. Acesso em 16 fev. 2020.

CAZELLI, S.; VALENTE, M. E. Incursões sobre os termos e conceitos da educação museal. Revista Docência e Cibercultura, Rio de Janeiro, v. 3, n. 2, p. 18-40, maio/ago. 2019.

CHIN, C. C. Museum experience - a resource for science teacher education. International Journal of Science and Mathematics Education, v. 2, p. 63-90, 2004.

CURY, M. X. Educação em museus: panorama, dilemas e algumas ponderações. Ensino Em Re-vista, v. 20, n. 1, p. 13-28, jan./jun. 2013.

FALK, J. H. Contextualizing Falk's Identity-Related Visitor Motivation Model, Visitor Studies, v. 14, n. 2, p. 141-157, 2011.

FALK, J. H. Três questões básicas sobre os visitantes de museus. Ensino Em ReVista, v. 20, n. 1, p. 69-82, jan./jun. 2013.

FALK, J. H.; DIERKING, L. D. Recalling the Museum Experience. Journal of Museum Education, v. 20, n. 2, p. 10-13, 1995. 
FRANCO, M. I. M. Museus: agentes de inovação e transformação. Cadernos de Sociomuseologia, v. 57, n. 13, p. 13-27, 2019.

GIL, A. C. Como elaborar projetos de pesquisa. 4. ed. São Paulo: Atlas, 2002, $176 \mathrm{p}$.

INSTITUTO BRASILEIRO DE MUSEUS (Ibram). Plano Nacional Setorial de Museus 2010/2020. Brasília, DF: MinC/Ibram, 2010. Disponível em: https://www.museus.gov.br/wp-content/uploads/2012/03/PSNM-VersaoWeb.pdf. Acesso em: 05 nov. 2020.

INSTITUTO BRASILEIRO DE MUSEUS (Ibram). Caderno da Política Nacional de Educação Museal. Brasília, DF: Ibram, 2018. Disponível em:

https://www.museus.gov.br/wp-content/uploads/2018/06/Caderno-daPNEM.pdf. Acesso em: 05 nov. 2020.

INSTITUTO BRASILEIRO DE MUSEUS (Ibram). Cadastro Nacional de Museus. Disponível em: https://www.museus.gov.br/acessoainformacao/acoes-eprogramas/cadastro-nacional-de-museus/. Acesso em: 31 dez. 2020.

INTERNATIONAL CONCIL OF MUSEUMS (ICOM). Disponível em:

https://icom.museum/en/resources/standards-guidelines/museum-definition/. Acesso em: 12 fev. 2020.

MACMANUS, P. Educação em museus: pesquisas e prática. São Paulo: FEUSP, 2013.

MARANDINO, M. (Org.). Educação em Museus: a mediação em foco. São Paulo, SP: Geenf/FEUSP, 2008.

MINISTÉRIO DA CIÊNCIA, TECNOLOGIAS, INOVAÇÕES E COMUNICAÇÕES (MCTIC). Recursos humanos - indicadores sobre o ensino de pós-graduação. 2019. Disponível em:

https://www.mctic.gov.br/mctic/opencms/indicadores/detalhe/Recursos_Hu manos/RH_3.5.5.html. Acesso em: 19 fev. 2020.

OLIVEIRA, G. C. G. et al. Visitas guiadas ao museu nacional: interações e impressões de estudantes da educação básica. Ciência \& Educação, Bauru, v. 20, n. 1, p. 227-242, 2014.

SARDELICH, M. E. Desafios contemporâneos para a educação museal. Interfaces da Educação, Paranaíba, v. 8, n. 23, p. 182-207, 2017.

SIDONE, O. J. G.; HADDAD, E. A.; MENA-CHALCO, J. P. A ciência nas regiões brasileiras: evolução da produção e das redes de colaboração científica. Transinformação, Campinas, v. 28, n. 1, p.15-31, jan./abr. 2016. 
SOUZA, V. M.; SILVA, A. M. M. A experiência museal sob a perspectiva do Modelo Contextual de Aprendizagem: uma compreensão a partir das memórias de longo prazo dos visitantes. Indagatio Didactica, Aveiro, v. 8, n. 2, p. 78-93, 2016.

TRAINER, L.; STEELE-INAMA, M.; CHRISTOPHER, A. Uncovering Visitor Identity: a citywide utilization of the Falk Visitor-Identity Model. Journal of Museum Education, v. 37, n. 1, p. 101-114, 2012.

TRAN, L. U.; GUPTA, P.; BADER, D. Redefining Professional Learning for Museum Education. Journal of Museum Education, v. 44, n. 2, p. 135-146, 2019.

Recebido em: 20 de janeiro de 2021. Aprovado em: 10 de março de 2021. Publicado em: 25 de março de 2021. 